\title{
Problems and Countermeasures of The Migrant Workers Becoming A Member of The City
}

\author{
Wenhua Kong \\ Basic department , Baoding College, Baoding, Hebei, 071000,China. \\ kjiansuoz@163.com
}

\begin{abstract}
Migrant workers becoming a member of the city is a typical "three rural" issue, it is related to China's social transformation and changes in social structure as well as the construction of socialist modernization with Chinese characteristics
\end{abstract}

Keywords-Migrant workers, member of the city, the urbanrural dual system, the household registration system.

\section{Introduction}

Migrant workers becoming a member of the city is a process that is the migrant workers who have left their residence for more than six months and work or do business in the city transform gradually to the resident. It mainly reflects in many aspects such as the account properties, housing, occupation, and cultural. With the rapid growth of china's economy, a large number of rural surplus labor force engaging in non-agricultural industries flocked to the city, but the Migrant workers can not be the city's residents successfully because of barriers of the urban-rural dual system, they experienced "migrant workers", it is a particular form of transition. So the issue of migrant workers came into the public. Migrant workers becoming a member of the city is a typical "three rural" issue, it is related to China's social transformation and changes in social structure as well as the construction of socialist modernization with Chinese characteristics.

\section{The historical evolution of the policy in migrant} workers becoming a member of the city

In the initial period of the establishment of new china, farmers fully enjoy the right to move to cities freely, the channel that farmers transform to the resident is smooth. However free movement of peasants to the cities meet the large-scale urban economic development in the demand of the labor, it put great pressure on Urban employment and food supply, most seriously, it make a direct impact on agriculture production. The government began to strictly make a limit on city enterprise recruiting workers from the countryside. In 1958, the government promulgated the "Household Registration Regulations",

then further implemented the food supply system, employment system, housing system, education system, etc, which is matched with the household registration system. After the 60s, almost all urban employment and living are

Project supported by Baoding College for Social Sciences Research (No.2010S08) controlled by the state, under the extremely strict household register control system, only by the national recruiting of workers, enlisting in the military and entering a higher school, can the farmers transform to the resident.

In order to adapt to the socialist market economic system, respect the creation and selection of farmers, countries have adjusted duly the policies, promoted the reform, gradually relaxed the farmers' working in cities and residence restriction since the reform and opening up.In the 1980s the government started to encourage the rural labor force " leaving the fields but remaining in the countryside, entered the plant not to enter a city"; After the 90s, in order to meet the requirements of large-scale trans-regional mobility of the rural labor force, the state transfer of rural labor employment policies gradually shift toward recognizing the flow, accepting the flow, encouraging the flow. In 2002, the Central Committee proposed a policy on the farmers' employment in the city "fair treatment, reasonable guidance, improved management, good service", in the later, it has released a series of policies, such as cleaning up and canceling the discriminatory regulations and unreasonable fees, simplifying inter-regional employment and a variety of procedures in working in the cities, protecting the legitimate rights and interests of migrant farmers.

Since the Sixteenth People's Congress, the policy of the Migrant workers has made a great breakthrough. In 2006, the government promulgated the "State Council on the issue of migrant workers to solve a number of opinions", the "PRC Employment Promotion Law" "PRC Labor Contract Law", "PRC Labor Dispute Mediation and Arbitration Law" and other important policies and regulations, formed the rural employment policy system, greatly enhanced efforts to protect rights, which has which are the most concerned about, the most direct and practical interests for the migrant workers from the strategic perspective of building a harmonious society, Comprehensively promoted the work of migrant workers, has made significant progress in the maintenance of the legitimate rights and interests of migrant workers. Although we have not used the policy statement "make the migrant workers become residents", there is no doubt that the policy intent that will promote the migrant workers to obtain the identity and rights of the public. Moreover, some important policy changes also created the conditions for the people of migrant workers. 


\section{The present situation and existence question for migrant workers becoming residents}

\section{A The present situation for migrant workers becoming residents}

Since the reform and open policy, the peasant laborer has gone into a city to get employed and the scale expanded unceasingly. According to the data released by the National Bureau of Statistics: In 1983 the number of migrant peasant workers are 1.5198 billion, in 2009, the number are 200 million, as shown in Table 1, form 2000 to 2009 the change in the number of migrant workers in Table [1], Table 2, employment of Migrant workers in the regional distribution in 2003 and 2008 [1]. The data indicated that migrant workers have been various regions across the country, and became an important part of industrial workers.

Table 1. the number of migrant workers in the main years since 2000 (million)

\begin{tabular}{|c|l|l|l|l|l|l|l|l|l|l|}
\hline Years & 2000 & 2001 & 2002 & 2003 & 2004 & 2005 & 2006 & 2007 & 2008 & 2009 \\
\hline $\begin{array}{c}\text { Quantit } \\
\mathrm{y}\end{array}$ & 7849 & 8399 & 10470 & 11390 & 11823 & 12578 & 13181 & 13611 & 14041 & 15198 \\
\hline
\end{tabular}

Table 2. The regional distribution of employment of migrant workers in the partial year(\%)

\begin{tabular}{|c|c|c|c|}
\hline Years & Eastern area & Middle area & Western area \\
\hline 2003 & 69.9 & 14.9 & 15.2 \\
\hline 2006 & 70.1 & 14.8 & 14.9 \\
\hline 2008 & 71 & 13.2 & 15.4 \\
\hline 2009 & 62.5 & 17 & 20.2 \\
\hline
\end{tabular}

B The existence question for migrant workers becoming residents

Although the migrant workers becoming residents has made significant progress, the rights of migrant workers has not been effective protected, the policy and management system for the migrant workers has not really get rid of urban-rural dual structure.

1) The peasant laborer cannot enjoy the urban collective services equally

Migrant workers' children have not integrated the inflow to handle fairly the compulsory education system. According to the survey made by National Bureau of Statistics in 2006: some $17 \%$ peasant laborer have children accompanying and goes to school in the local city, the ratio is about 7:3 in the public schools, migrant children schools. The most managed by the people peasant laborer Dependent's school cannot obtain government's support, its compulsory education funds have not been included the fiscal budget. They only depended on collecting fees from migrant workers to maintain the revolution, affected the quality of education, increased the burden on migrant workers. Migrant workers can not be equal access to immunization programs, disease prevention and surveillance, public health services, family planning services.

2) Social security rights and interests of the migrant workers cannot obtain the effective safeguards

At present, the proportion of the old-age insurance in which the peasant laborer participates is very low. As the payment threshold of the old-age insurance is high and the peasant laborer flows frequently, the majority of migrant workers is difficult to achieve the life standards of the insured. Migrant workers are not covered by the city medical assistance (relief illness) range, and urban permanent residents can not enjoy the same medical assistance benefits.

3) The housing of migrant workers has not been integrated into the cities" housing safeguard system.

Peasant laborer in urban housing mainly depending on three kinds of channel solutions: Purchasing the innate property right room, providing the housing by the employing labor unit, renting the housing voluntarily from the market. The proportion for the migrant workers Purchasing the innate property right room is very low, the main units providing accommodation are large industrial park of some enterprises, construction companies, accommodation, catering and other services enterprises, the major part of peasant laborer's housing situation voluntarily are solved by individual, they rent a room primarily. Because the income is low, the peasant laborer can only rent in the city where the condition is worst, the rent is the lowest. Currently, the city's affordable housing, low-cost housing and other public housing are basically not open to migrant workers, migrant workers are still divorced from the urban housing security system.

4) The household register threshold that the peasant laborer settles down in the cities is high

The peasant laborer and the cities household register population in the housing, education, social security and other aspects can not enjoy equal welfare systems, which are attached to the top of the household registration system. The long-term household register separation causes the peasant laborer to be unable to enjoy many welfare which can been enjoyed by the cities staff. The lateral economic ties raised the threshold which the peasant laborer enters a city, caused the urbanization to be at refuses to compromise the condition,

became a barrier that the peasant laborer seek the opportunity to be fair, the treatment equality, the rights and interests safeguard, limited the peasant laborer to integrate the urban society.

\section{5) The peasant laborer's income level is low}

With the interests of migrant workers in recent years, the demands of national importance and their quality of migrant workers continues to increase, wages for migrant workers has increased, although this, wages for migrant workers are still at a relatively low level, it can be performed in unequal pay for co-workers and urban workers, wage labor and the actual contribution of the dislocation. In Hebei, for example, as shown in Table 3 migrant peasant workers, the 
comparison table [2], [3] between the average wage and salary in Hebei Province. Compared with the provincial average wage, migrant wages of migrant workers is much lower in Hebei province.

Table 3 . The comparison table between the average wage and salary of Hebei Province peasant workers (yuan / month)

\begin{tabular}{|c|c|c|c|c|c|c|}
\hline years & 2002 & 2003 & 2004 & 2005 & 2006 & 2007 \\
\hline Migrant wages of migrant workers & - & - & 337 & 411 & 496 & - \\
\hline Average wage in Hebei Province & 836 & 932 & 1077 & 1225 & 1382 & 1659 \\
\hline
\end{tabular}

6) The peasant laborer's culture quality is somewhat low

State Statistical Bureau's data demonstrated that in 2006 the illiterate accounted for $1.8 \%$, primary education accounted for $14.3 \%$, junior middle school education accounted for $67 \%$, high school education accounted for $11.1 \%$, secondary and higher education accounted for $5.8 \%$ in the migrant labor force of these, $64.8 \%$ of the workforce out never received any form of skills training .

\section{IV.The countermeasure analysis to speed up the peasant laborer becoming resident}

The above question that the peasant laborer faced closely is fundamentally related with the China's household registration system. In our country lateral economic ties have adhered to a series of township dwellers welfare systems, including the housing system, the lowest social security system, medical and the old-age insurance system, the children enters a higher school the system and so on. Household registration system reform belongs to the deep level between the city and countryside resident benefit and the omni-directional adjustment, it is impossible to get it done in one action. Migrant workers becoming resident will be accompanied by industrialization, urbanization and solving the issue of "three rural", passing through the entire stage in realizing the well-off society by 2020 . Therefore, the government must adroitly guide action according to circumstances in the policy of peasant laborer becoming resident, advance with steady steps. The basic philosophy starts with the easy and then does the difficult: "The recent measures": first urban education, welfare, housing and other public goods are showed to the migrant workers gradually; "forward goal": Completing the lateral economic ties reform, realizing the peasant laborer becoming resident finally.

\section{A The recent measures to promote the migrant workers to become resident}

The key for the migrant workers becoming resident is that migrant workers can not share the city's public goods which put them in the survival disadvantage in basic necessities of life, education development. Under the circumstance of the reform of household registration system can not be completed in the short term, the city gradually increase the share proportion of urban public goods to the migrant peasant workers

1)we can completely cover the public service system of urban migrant workers, show equal treatment to the migrant workers. The government takes the migrant workers as the part of the city's people, makes the migrant workers that make a living, get employed, housing and public service needs for education, health care, security, entertainment into consideration from the overall urban planning.

2)The safeguard system covers peasant laborer's cities housing. The migrant workers who have Stable employment for a certain number of years in the city and certain economic capacity should be given the resident's treatment in the indemnificatory housing and be provided low-cost housing, affordable housing, commercial housing price compared with the urban income standards.

3)The social security system covers migrant workers, such as realizing the workers' compensation insurance as soon as possible to the peasant laborer, Perfecting peasant laborer's medical service system of safeguards, Enhancing the old-age insurance to peasant laborer's coverage.

4)In order to alleviate coastal and the big or media-sized cities' collective services huge pressure, strengthen the small cities' buying in ability, we should encourage the peasant laborer nearby becoming resident.

5)Make the land contracting power circulation system perfect, truly protect the public in the process of land rights.

\section{$B \quad$ Promote the long-term goal of migrant workers becoming residents}

The long-term goal for promoting migrants becoming resident is to eventually comply with the requirements of migrant workers and further reform the household registration system, to improve migrant peasant workers' sense of belonging and identity. The goal to reform the household registration system is to cancel the agricultural registered permanent address around the country, the non-agricultural registered permanent address division, establish the city and countryside unified household registration system. At the same time, it promotes the labor employment, the social security, the compulsory education, health and other nature-related administrative and account management, social management system reform, realizes the city and countryside resident' status unification, the equal opportunity, the right equality finally.

\section{References}

[1] State Statistical Bureau website, http://www.stats.gov.cn/ New China Net Hebei channe

[2] http://www.hbfzweb.com/html/200702/05/083712895

[3] bean Ding net, http://www.docin.com/p-93296846.html

[4] State Statistical Bureau website, http://www.stats.gov.cn/ 